\title{
DMAIC MANUAL FOR AN INTEGRATED MANAGEMENT SYSTEM: APPLICATION IN A CONSTRUCTION COMPANY
}

\author{
Mariana Bravo', Camila Augusto Euphrosino², \\ and Patricia Stella Pucharelli Fontanini ${ }^{3}$
}

\begin{abstract}
This article elaborates on the development of a DMAIC Manual for the restructuring of an Integrated Management System of a Brazilian company that builds real estate and corporate works, with a focus on Lean Six Sigma.

The Manual was designed to lead the XYZ construction company toward a management focused on Lean Six Sigma, reducing waste and variability of its delivery processes to customers. The five DMAIC steps - define, measure, analyze improve and control - were reviewed and structured to add value to activities.

The structuring and implementation of this Manual are detailed, including the management history of the company and how the Integrated Management System relates to the DMAIC.
\end{abstract}

\section{KEYWORDS}

Continuous improvement, integrated management system, lean construction, process, six sigma.

\section{INTRODUCTION}

The main theory that drives this article is Lean Thinking. This thought arose with the need to develop the automotive industry, which it combined as advantages of artisanal and mass production (Dennis, Kosaka and Garcia, 2008). The basic characteristic of thinking is to eliminate waste in the production chain, such as overproduction, movement, transportation, stock, waiting, unnecessary activities and defects (Ohno, 1988), apart from adding greater value to the final product and providing continuous improvement.

In 1992, Lean Thinking began to be disseminated in civil construction with the work of Finnish researcher Lauri Koskela (Lean Construction). Civil construction traditionally carried out an irrational production system, with a high rate of losses and a high cost of production. Even today, construction is a very complex undertaking, which depends on

1 PhD Candidate, Architecture and Construction Department, School of Civil Engineering, Architecture and Urban Design, UNICAMP - University of Campinas, São Paulo, Brazil. maribravothz@gmail.com. orcid.org/0000-0001-9330-0755

2 MSc Student, Architecture and Construction Department, School of Civil Engineering, Architecture and Urban Design, UNICAMP - University of Campinas, São Paulo, Brazil. ceuphrosino@gmail.com. orcid.org/0000-0002-7924-7414

3 Professor, Architecture and Construction Department, School of Civil Engineering, Architecture and Urban Design, UNICAMP - University of Campinas, São Paulo, Brazil. pspucha@gmail.com. orcid.org/0000-0002-7532-7505/ 
several factors, such as the quality of materials and labour, and the resources available, factors that when not controlled cause waste.

One of the practices currently used to introduce lean thinking in the quality management of companies is Six Sigma, which also had its origin in the manufacturing industry, more specifically in the Motorola company (Carvalho, 2012), in 1986. This practice aims to control the variability and stability of processes, using mathematical and statistical tools (Harry, 1998). Using the Six Sigma model, companies are able to decrease their defect rates and thereby increase their competitiveness in the face of the globalization of the current market (Carvalho, 2012).

The application of the Six Sigma methodology follows the five-step process: defining, measuring, analysing, improving and controlling (DMAIC) (Lean Enterprise Institute, 2016). In the first phase, the client's requirements are defined and what is expected from the project. In the second, the process data is obtained, defining the inputs and outputs. In the analysis phase, statistical tools are used to obtain a better view of the process. Improvement is a critical step in which the process will be modified. The last phase of control aims not allowing the process to go into disorder in the future (Carvalho, 2012). It is possible to eliminate defects, rise quality of final products, in addiction to generating benefits of continuous improvement in production, with this integrated management system,

Six Sigma methodologies have passed and are still undergoing constant evolution. So that, despite having its origin in the manufacturing industry, several business sectors have already applied in quality management, such as the food industry (Tannady et al, 2019) and the agro-industry (Conceição et al., 2019).

Specifically in civil construction, the implementation of Six Sigma has already shown excellent results due to its systematic approach in solving problems such as, for example, the invention of a new earthquake-proof construction method in Taiwan (Lee and $\mathrm{Su}$, 2013). The use of process mapping tools, C\&E (cause and effects) Matrix and analysis of failure modes and effects (FMEA), Lee and Su (2013) were able to study all the variables that generated cracks in the lightweight partition walls, reducing the cracks produced by earthquakes.

Other examples in the construction sector are the application of Six Sigma in the concrete plants. In a production of concrete panels it was possible to reduce the rates of production variation, analysing the defects and their root causes through the Six Sigma methodology (Oguz et al., 2012). In a concrete block plant, there was a reduction in material waste from 18 to $2 \%$, in addiction to decreases in machine downtime and increased productivity with layout changes and improvements in facilities provided by the application of Six Sigma logistics in production (Morales et al., 2016).

Despite this, the bibliographic contribution on the application of Six Sigma with Lean construction is overwhelming, especially when talking about Brazil (Silva et al., 2018). Thus, this article aims to demonstrate a case study in a company in the civil construction area that developed a guide for the application of Six Sigma practice.

\section{APPLICATION}

The implementation of a Manual for an Integrated Management System with a focus on Lean Six Sigma, using DMAIC as a structure for the dissemination of waste reduction and simultaneously reducing the variation of the delivered products, is the description of this work. 
This implementation took place in 2017, in an XYZ construction company under the responsibility of one of the researchers, who in this period was a quality coordinator and lean six sigma specialist.

\section{COMPANY}

The activities of the construction company XYZ focus on the execution of industrial works for private clients and real estate works of medium and high standard of finishing in Brazil, since 1983. To serve the clients of these construction segments, it implemented a quality management system after the organizational restructuring between 2001 and 2008. In 2009, its quality management system obtained certification under the ISO 9001 version 2008 standard and the PBQP-H (Brazilian Program for Quality and Productivity in Habitat).

In 2013, through the AQUA-HQE Reference (International certification of sustainable construction that developed from the French Haute Qualite Environnemental certification) is being used by Brazilian Construction Companies since 2008), the quality management system is adapted to meet the environmental quality requirements of real estate projects, and consequently, applicable requirements are also adopted for industrial works.

In 2016, the quality control department, together with the management of the construction company XYZ, decided to start the implementation of the integrated management system, aligning the requirements of the certification standards with requirements for work safety, the environment and occupational health, as well as the company's new strategic planning.

In the same period, Lean tools such as standardized work, cash management, $5 \mathrm{~S}$ program, application of kanban to control material stock were already applied to all works in progress: 03 (three) corporate works and 09 (nine) real estate works.

However, as there was still not enough to minimize technical assistance to completed works. Requests for adequacy of products already delivered were of the most varied, and for similar products. Example: for the same project, more than one housing unit had problems with hydraulic installations at different points.

Such problems led to unforeseen costs and impact on the image of the construction company XYZ, mainly in terms of quality and guarantee of the delivered product. Emphasizing that, many times the customers did not have technical knowledge in the area of civil construction, which increased their insecurity.

In the following year, in 2017, it was decided to take a step further in the integrated management system, to align it definitively with Lean Construction with a focus on total waste reduction and to simultaneously align with Six Sigma in order to reduce product variations and services, at the same time it was decided to request the update of the certification ISO 9001 version 2008 to version 2015.

The 2015 version of the ISO 9001 standard was revised considering a structure aligned with other management standards, terms such as product and services outlined as process outputs, stakeholder needs and expectations, risk management, documented information, organizational knowledge, and finally control processes, products and services provided externally.

Figure 1 shows the timeline of management maturing of the XYZ company, summarizing what was described. 


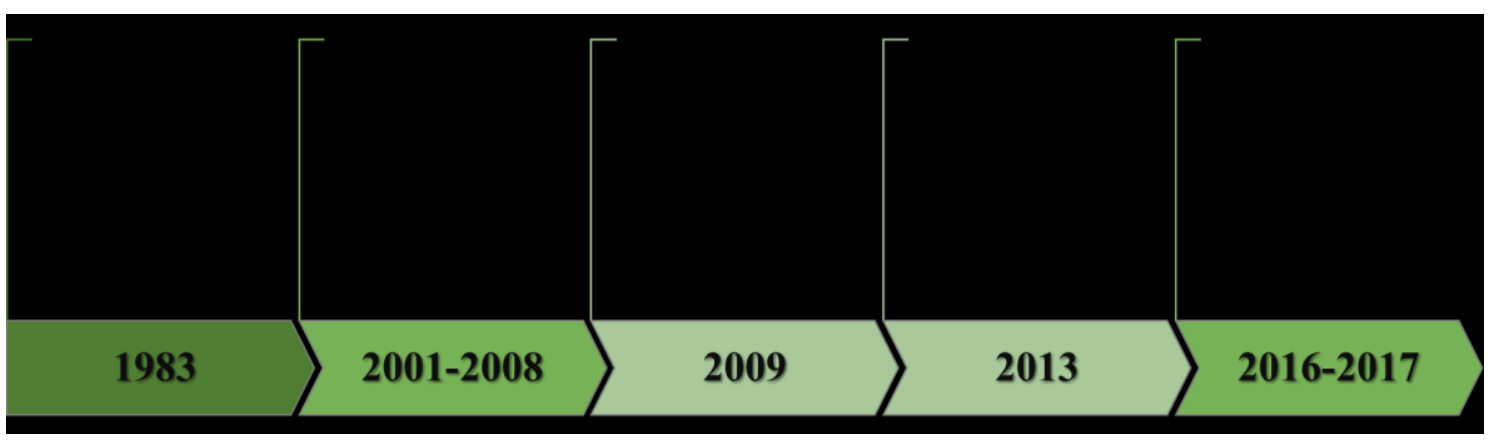

Figure 1: Timeline of management maturing (Authors)

\section{INTEGRATED MANAGEMENT SYSTEM}

The Integrated Management System (IMS) was a way of managing in the light of the vision, values and strategic planning of the construction company $\mathrm{XYZ}$, and not only under the requirements required in the reference standards for certification. The standards used as references for applied certification are shown in Figure 2.

\begin{tabular}{|c|c|c|c|c|c|}
\hline \multicolumn{2}{|r|}{ CERTIFICATION } & \multirow[b]{2}{*}{$\begin{array}{c}\text { Maintainer/ } \\
\text { Country }\end{array}$} & \multicolumn{3}{|c|}{ PROJECT APPLICATION } \\
\hline Title & Objetctives & & 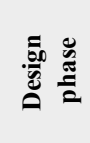 & 递 & 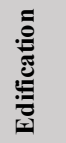 \\
\hline $\begin{array}{c}\text { Brazilian Habitat } \\
\text { Quality and } \\
\text { Productivity Program } \\
\text { Reference for } \\
\text { Construction Works } \\
\text { Execution }\end{array}$ & $\begin{array}{l}\text { It is an instrument of the Federal Government } \\
\text { to fulfill the commitments signed by Brazil } \\
\text { when the Istanbul Charter was signed (Habitat } \\
\text { Conference II / 1996). Its goal is to organize the } \\
\text { civil construction sector around two main } \\
\text { issues: improving the quality of the habitat and } \\
\text { modernizing production. Comprised of the } \\
\text { systems: Conformity Assessment System for } \\
\text { Construction Service and Construction } \\
\text { Companies, Qualification System for Materials, } \\
\text { Components and Construction Systems } \\
\text { Companies, National Technical Assessment } \\
\text { System. }\end{array}$ & $\begin{array}{c}\text { Ministry of Cities } \\
\text { Federal Government } \\
\text { Brazil }\end{array}$ & $\mathrm{X}$ & $\mathrm{X}$ & $\mathrm{X}$ \\
\hline ISO 9001:2015 & $\begin{array}{l}\text { This is standard specifies the requirements for a } \\
\text { quality management system applicable to any } \\
\text { organization that needs to present its capacity } \\
\text { for customer service, as well as increase } \\
\text { customer satisfaction. }\end{array}$ & $\begin{array}{c}\text { ABNT } \\
\text { (Brazilian } \\
\text { Association of } \\
\text { Technical Standards) }\end{array}$ & $\mathrm{X}$ & $\mathrm{X}$ & $X$ \\
\hline $\begin{array}{l}\text { AQUA-HQE } \\
\text { Certification }\end{array}$ & $\begin{array}{l}\text { Establishes guidelines for the design, planning } \\
\text { and execution of housing buildings with high } \\
\text { environmental quality. Through audits and } \\
\text { analyzes in the pre-project, project and } \\
\text { execution phases, they attest to the } \\
\text { undertaking's performance in terms of } \\
\text { sustainability requirements, as well as to the } \\
\text { entrepreneur to execute sustainable works. }\end{array}$ & $\begin{array}{c}\text { Vanzolini } \\
\text { Foundation } \\
\text { Brazil }\end{array}$ & $\mathrm{X}$ & $\mathrm{X}$ & $\mathrm{X}$ \\
\hline
\end{tabular}

Figure 2: Company certifications (Authors)

The certifications of the Integrated Management System (IMS) under the aforementioned standards presented to construction, real estate and corporate clients that construction company XYZ had the ability to deliver to the customer the product and service that were 
requested. For society and the market, such certifications could present maturity in their organizational structure.

\section{SIX SIGMA}

The addition of Lean Six Sigma to the IMS started simultaneously the need to adapt the IMS to the new strategic planning of the construction company XYZ and to meet the revisions of the ISO 9001 and PBQP-H standards.

For the restructuring of the IMS, a committee was created, from functions already existing in the company's organizational chart (as shown in Figure 3), which would also participate in the implementation of the first steps for an IMS with a focus on Lean Six Sigma, as shown in Figure 4:

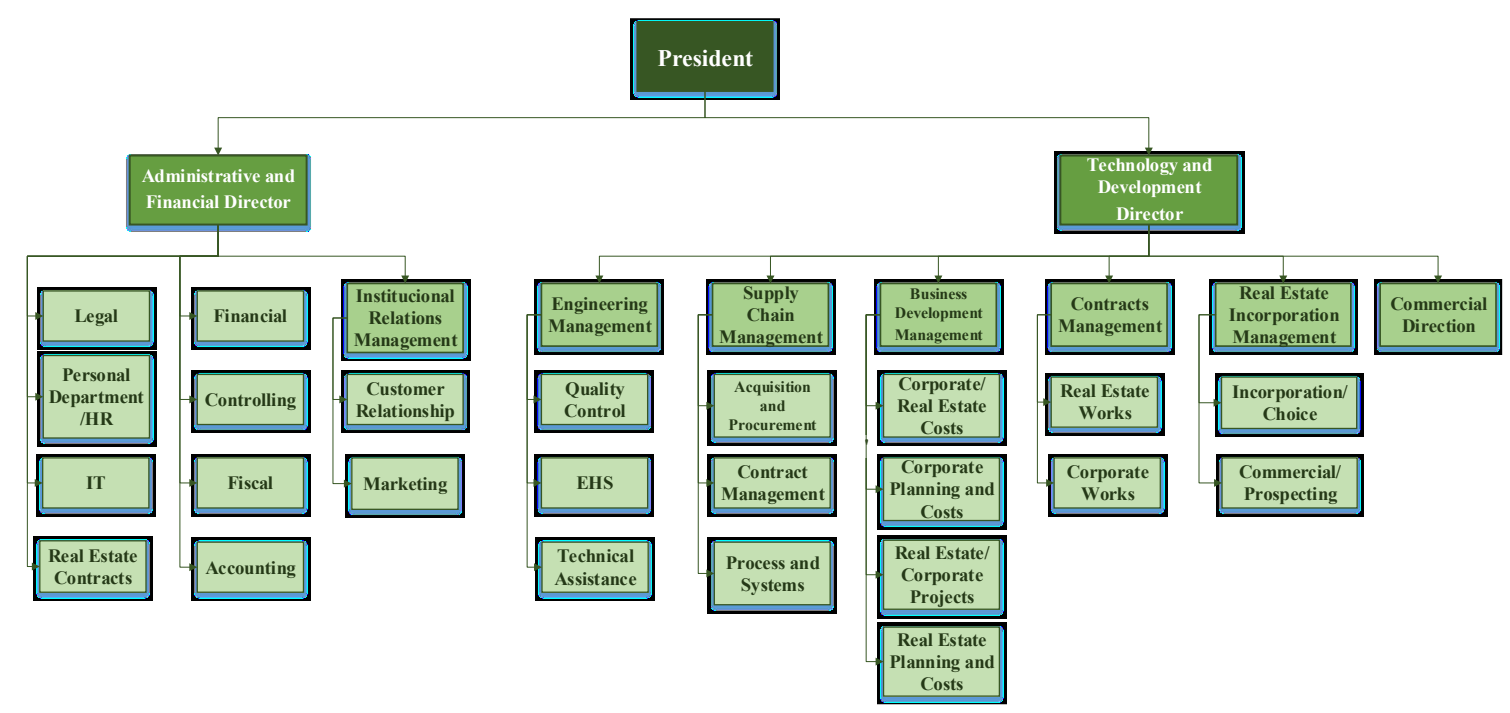

Figure 3: Organization Chart of Empresa Construtora XYZ (Authors)

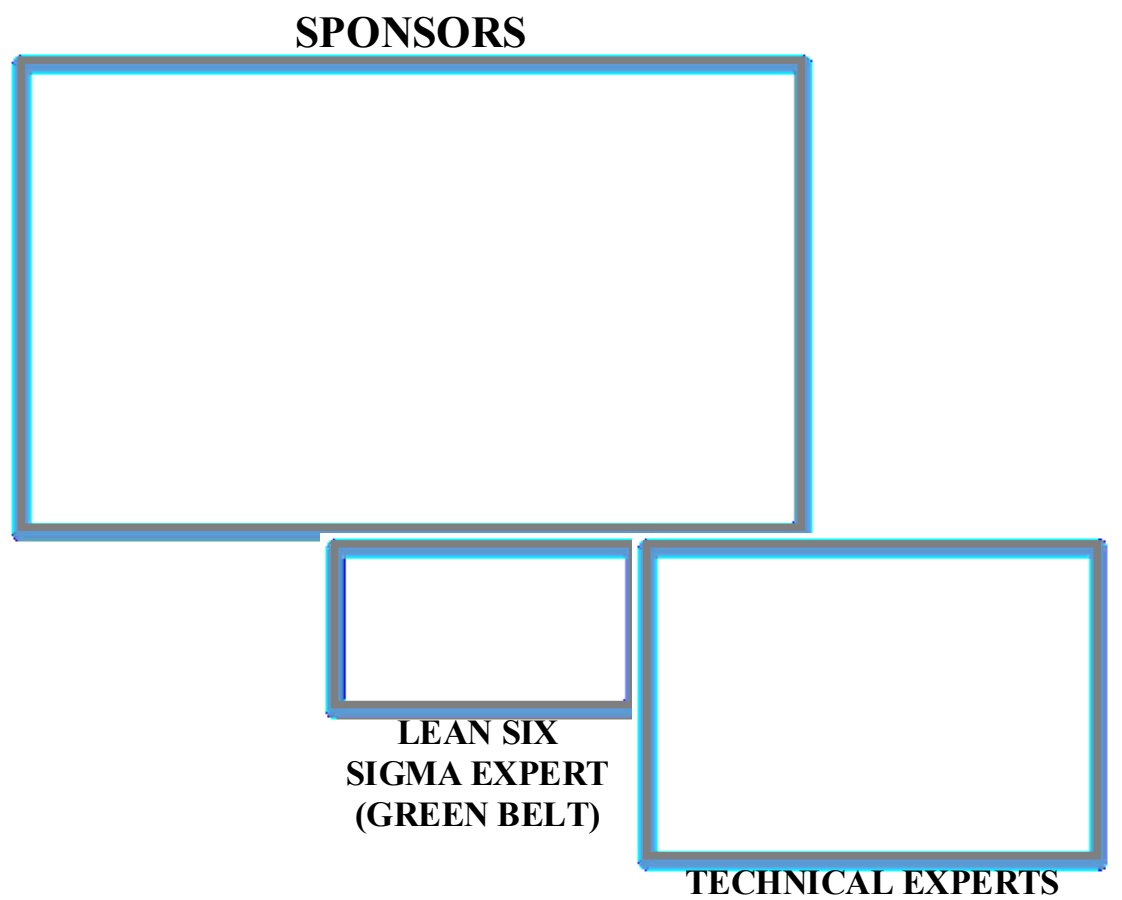

Figure 4: Organization chart of the IMS Lean Six Sigma Committee (Authors) 
DMAIC Manual for an Integrated Management System:

Application in a Construction Company

The committee started working in the first two months of 2017, according to the schedule shown in Figure 5.

\begin{tabular}{|c|c|c|c|c|c|c|c|c|c|c|c|}
\hline \multicolumn{12}{|c|}{ Schedule - 2017} \\
\hline \# & Activity & Responsible & 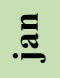 & $\stackrel{0}{\varrho}$ & $\stackrel{\grave{\Xi}}{\Xi}$ & $\overline{\frac{a}{\sigma}}$ & 突 & $\Xi$ & $\Xi$ & $\stackrel{200}{\Xi}$ & 융 \\
\hline 1 & $\begin{array}{l}\text { Form the committee: establish } \\
\text { the activities for the } \\
\text { implementation of the IMS } \\
\text { Lean Six Sigma }\end{array}$ & Sponsors & & & & & & & & & \\
\hline 2 & $\begin{array}{l}\text { Change of the PDCA cycle to } \\
\text { DMAIC cycle }\end{array}$ & $\begin{array}{l}\text { Lean Six Sigma Expert (Green } \\
\text { Belt) }\end{array}$ & & & & & & & & & \\
\hline 3 & $\begin{array}{l}\text { Define: definition of the } \\
\text { organization and its context, } \\
\text { based on the requirements of } \\
\text { the Client and the market in } \\
\text { which it operates }\end{array}$ & $\begin{array}{l}\text { Sponsors, Lean Six Sigma } \\
\text { Expert (Green Belt) }\end{array}$ & & & & & & & & & \\
\hline 4 & $\begin{array}{l}\text { Measure: how IMS processes } \\
\text { are performed measured }\end{array}$ & $\begin{array}{l}\text { Lean Six Sigma Expert (Green } \\
\text { Belt), Technical Experts }\end{array}$ & & & & & & & & & \\
\hline 5 & $\begin{array}{l}\text { Analyse: analysis of the } \\
\text { behavior of processes and } \\
\text { performance indicators }\end{array}$ & $\begin{array}{l}\text { Lean Six Sigma Expert (Green } \\
\text { Belt), Technical Experts }\end{array}$ & & & & & & & & & \\
\hline 6 & $\begin{array}{l}\text { Improve: improvements to } \\
\text { existing processes and their } \\
\text { effects on the company are } \\
\text { monitored, proposed and } \\
\text { evaluated }\end{array}$ & $\begin{array}{l}\text { Lean Six Sigma Expert (Green } \\
\text { Belt), Technical Experts }\end{array}$ & & & & & & & & & \\
\hline 7 & $\begin{array}{l}\text { Control: actions are taken so } \\
\text { that the processes reach their } \\
\text { goals in order to ensure that the } \\
\text { Client's requirements are being } \\
\text { met }\end{array}$ & $\begin{array}{l}\text { Lean Six Sigma Expert (Green } \\
\text { Belt), Technical Experts }\end{array}$ & & & & & & & & & \\
\hline 8 & $\begin{array}{l}\text { Complete the DMAIC Manual } \\
\text { for the IMS }\end{array}$ & $\begin{array}{l}\text { Sponsors, Lean Six Sigma } \\
\text { Expert (Green Belt), Technical } \\
\text { Experts }\end{array}$ & & & & & & & & & \\
\hline 9 & $\begin{array}{l}\text { Presents the DMAIC Manual } \\
\text { for the IMS for Managers }\end{array}$ & $\begin{array}{l}\text { Sponsors, Lean Six Sigma } \\
\text { Expert (Green Belt), Technical } \\
\text { Experts }\end{array}$ & & & & & & & & & \\
\hline 10 & $\begin{array}{l}\text { Presents the DMAIC Manual } \\
\text { for the IMS for others workers } \\
\text { from the company }\end{array}$ & $\begin{array}{l}\text { Lean Six Sigma Expert (Green } \\
\text { Belt), Technical Experts }\end{array}$ & & & & & & & & & \\
\hline 11 & $\begin{array}{l}\text { Deploy the DMAIC Manual to } \\
\text { the IMS }\end{array}$ & $\begin{array}{l}\text { Lean Six Sigma Expert (Green } \\
\text { Belt), Technical Experts }\end{array}$ & & & & & & & & & \\
\hline 12 & $\begin{array}{l}\text { ISO } 9001 \text { recertification } \\
\text { (2015 version) }\end{array}$ & $\begin{array}{l}\text { Sponsors, Lean Six Sigma } \\
\text { Expert (Green Belt), Technical } \\
\text { Experts }\end{array}$ & & & & & & & & & \\
\hline
\end{tabular}

Figure 5: Schedule for the implementation of SGI Lean Six Sigma (Authors)

After the composition of the committee and the schedule, the conversion from PDCA to DMAIC was carried out, as proposed by Werkema (2012) and shown in Figure 6. 


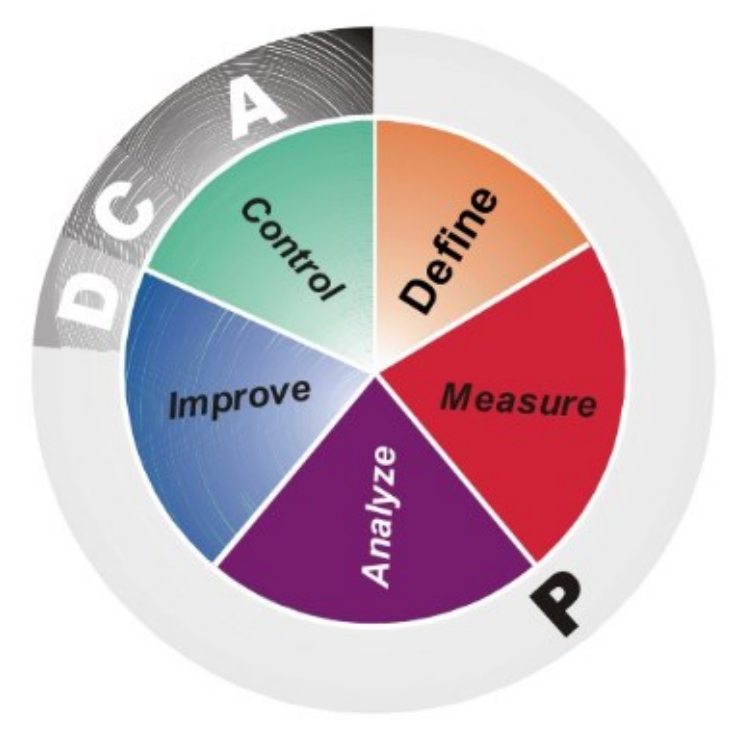

Figure 6: PDCA X DMAIC (in Werkema, 2012)

Abdelhamid (2003) defined the DMAIC frameworks:

1. Defining: identify the clients requiriments and the itens that can affect the results of processes;

2. Measuring: crucial datas to the problem through Six Sigma.

3. Analyzing: using management control tools to identify the causes of problems.

4. Improving: using methods obtained in the analysis phase.

5. Controlling: monitoring the process using process control to supports the improvements.

Different than the PDCA approach, DMAIC considers detailed steps, besides those that establish a focus on variability.

\section{DMAIC MANUAL}

Although the 2015 version of ISO 9001 does not require a quality plan or manual, the change of focus and the adequacy of the strategic planning of the construction company XYZ made it possible to compose a Manual that could direct everyone's steps on the same path.

The Integrated Management System Manual based on the DMAIC was divided into 05 (five) phases distributed in chapters, as shown in Figure 7. 


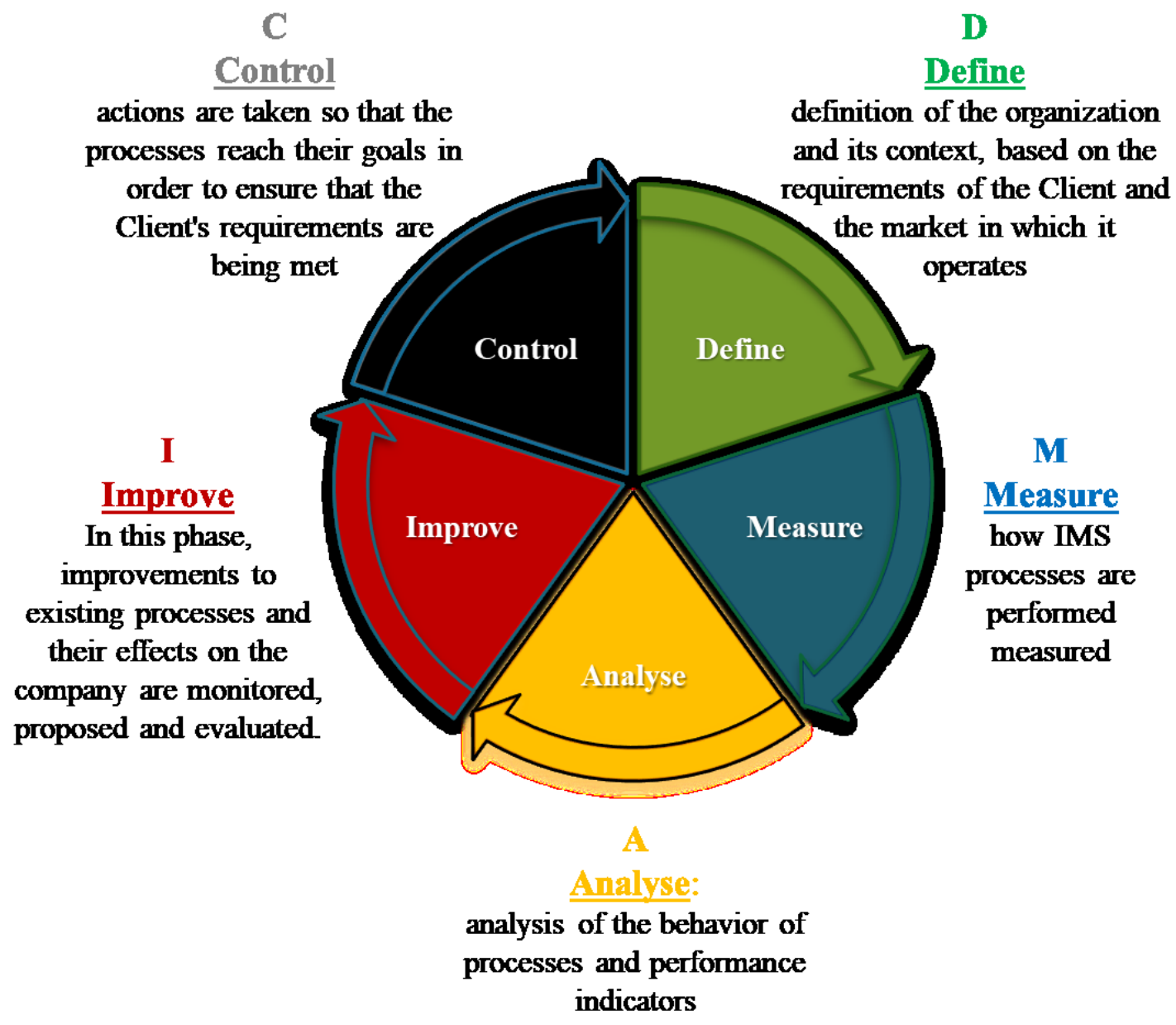

Figure 7: DMAIC Circle for the Integrated Management System (Authors)

Making an analogy to the PDCA: Plan - corresponds to the Define, Measure, Analyze steps; Do (Do) - corresponds to the Improve step; Check and Act - corresponds to the control step.

The stages and their respective organizational requirements corresponding to each of the 05 (five) DMAIC stages were detailed, as shown in Figures 8, 9, and 10.

The step Define aims to make clear how the company is organized and how business information is documented and what forms of access. The next step, Measure aims to present the corporate risk management tools, including risks to work safety, occupational health and the environment, as well as how to measure the construction company's objectives and goals (Figure 8). 


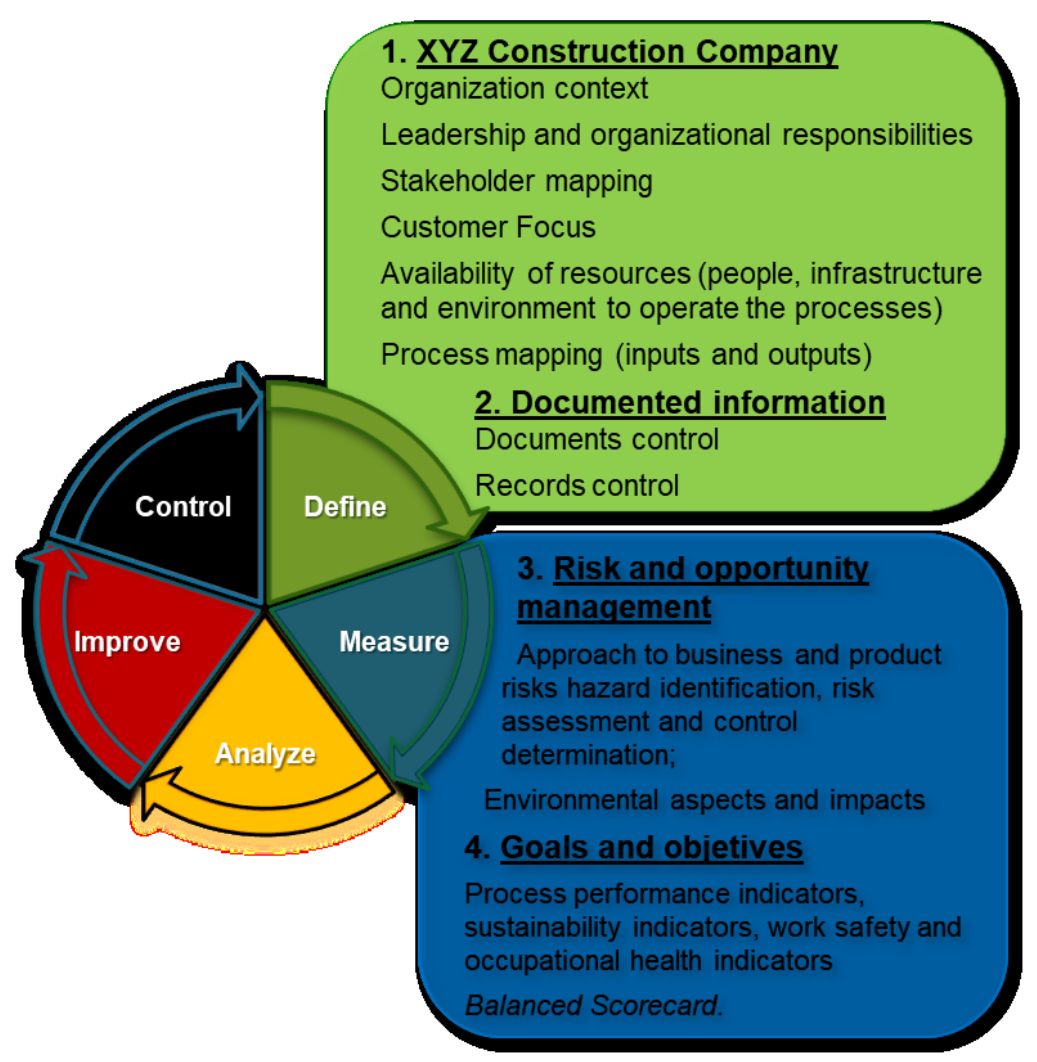

Figure 8: Define and Measure (Authors)

The step Analyse aims to present how the company, through the quality control tools, analyses the progress of process. Therefore this step includes audits and verifications (Figure 9).

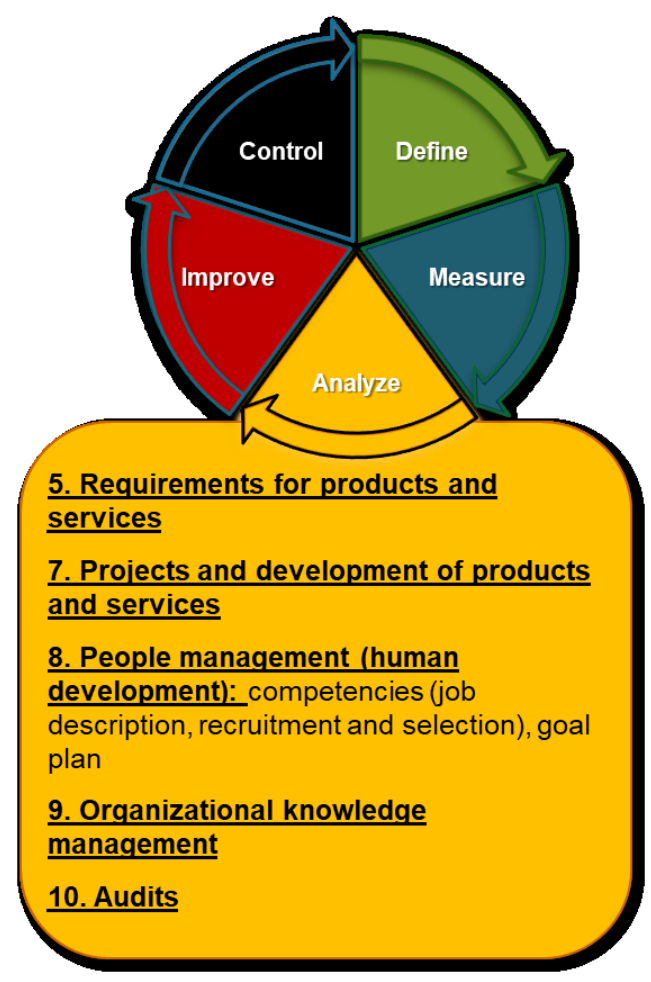

Figure 9: Analyse (Authors) 
The next step, Improve presents how the company treat the data obtained from the previous step, Analyse. The last step, Control, presents how the company holds procedures and resources to keep the control on the strategies, mainly checking client service (Figure 10).

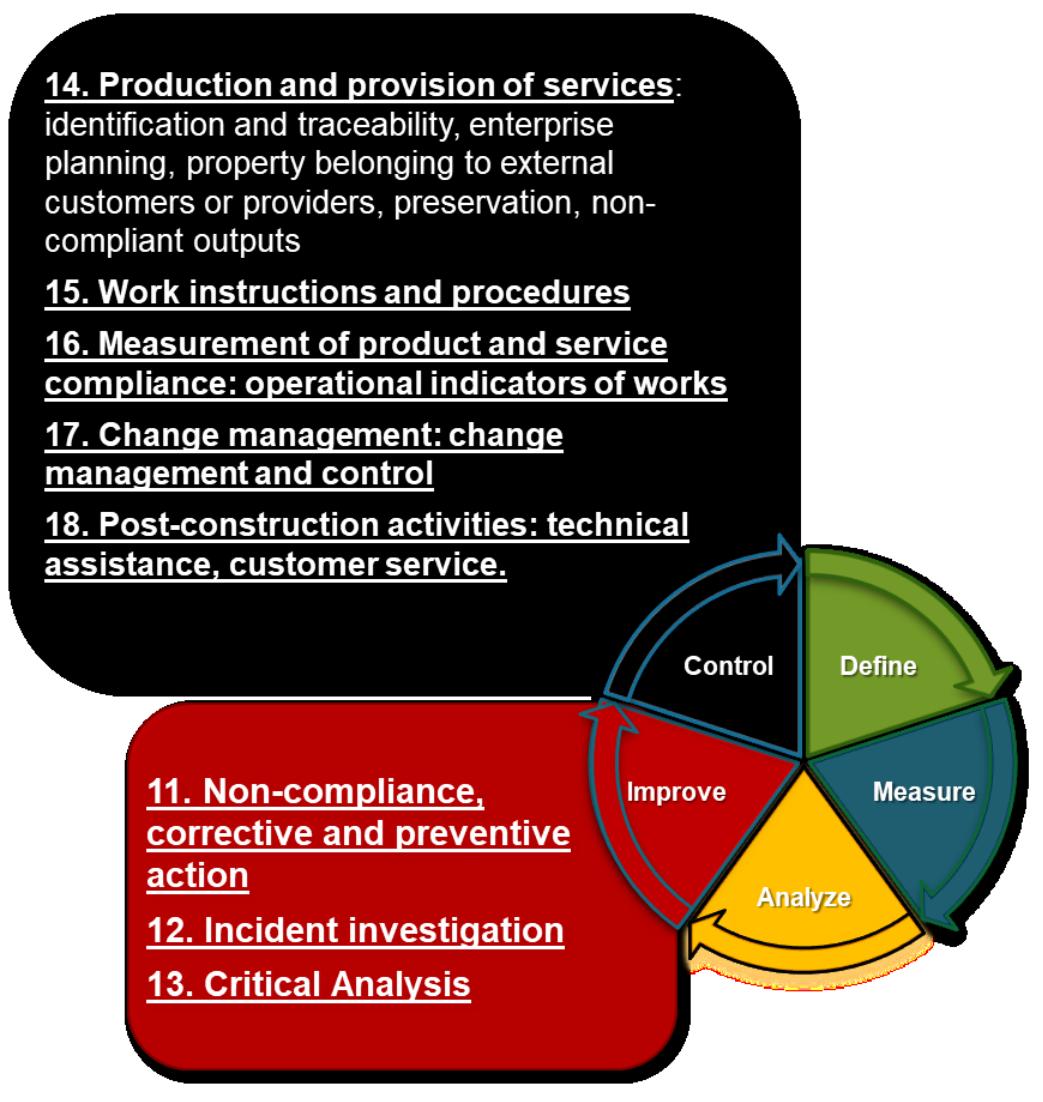

Figure 10: Improve and Control (Authors)

The information was compiled by the committee with the other departments of the company and the Manual was approved by the sponsors. Then it was introduced to the entire company through training and meetings.

Even though it is not a normative requirement, the Manual was still in use until 2019, according to information from the company itself.

\section{DISCUSSION AND RESULTS}

The change in focus started with Lean tools and later an Integrated Management Manual structured under the DMAIC, and had to have the committee in charge until the change was consolidated, dating back to the end of 2017.

As a result of the Manual and the management tools that were developed, implementation of an integrated management system was directed toward a Lean Six Sigma approach. It was found that activities and management processes showed greater variability in their results; for example, the budgets that were prepared for new works were designed according to the requirements of the future client, without considering the resources available within the company. The variability between budgets was noted, so the DMAIC Manual, procedures and indicators that covered the budgets' inputs and outputs brought linearity to the budgeting process, generating performance indicators regarding customer service. DMAIC is not new, however the application of the concept 
to structure a management system can be something that directs the organization toward Six Sigma.

The presentation to the managers of the construction company XYZ was made more difficult since it did not involve immediate financial measurement. Without effective payment of compliance by sponsors, the importance of the Manual was too complicated to be absorbed.

\section{CONCLUSIONS}

It was determined that activities and management processes must be structured according to the company's organizational maturity, not just to meet reference standards or to obtain certifications. One must first understand who they are and what their customers need in order to make valuable transformations.

For the best customer service, a management system focused on quality and that is sustainable is fundamental for the company.

\section{FUTURE RESEARCH}

There is a immense opportunity for the implementation of the Lean Six Sigma approach in civil construction, especially when it comes to management tools targeted. Manuals, business plans, standardized work procedures, Key Performance Indicators, Balance Score Cards for management focused on reducing waste and variability, may have their uses more explored on construction sites as well as at the headquarters of the construction company.

This practice of Lean Six Sigma tools and management systems for construction companies can be further explored in the academy with the presentation of models that can assist professionals in the implementation of more mature and leaner management systems.

\section{ACKNOWLEDGMENTS}

We appreciate the opportunity to explain the use of DMAIC to the higher education institution in which we operate, UNICAMP (State University of Campinas), for all the technical and scientific support. Even as CAPES (Coordination for the Improvement of Higher Education Personnel) for the financial subsidy to aid research in the area of construction process technology.

\section{REFERENCES}

Abdelhamid, T. S. 2003, 'Six-Sigma in Lean Construction Systems: Opportunities and Challenges' Proc. 11th Annual Conference of the International Group for Lean Construction. Virginia, USA, 1-.

Associoção Brasileira de Normas Técnicas (2015). ISO:9001 - Sistemas de gestão da qualidade - Requisitos. Rio de Janeiro.

Carvalho, M. (2012). (Gestão da qualidade: Teoria e Casos) Quality management: Theory and Cases. GEN LTC.

Conceicao, R. S., Pariz, M. C., da Silva, V. L., de Genaro Chiroli, D. M., and Aragao, F. V. (2019). "Lean Six Sigma: Implementation of Improvements to the Industrial Cost Management." Independent Journal of Management \& Production, 10(6), 20232045. 
Dennis, P., Kosaka, G. I., and Garcia, R. A. N. (2008). (Produção Lean Simplificada: Um Guia para Entender o Sistema de Produção Mais Poderoso do Mundo) Simplified Lean Production: A Guide to Understanding the Most Powerful Production System in the World. Bookman, Porto Alegre.

Harry, M. (1998). "Six Sigma: A breakthrough strategy for profitability." Qual. Prog. $31(5), 60-64$.

Koskela, L. (1992). Application of the new product philosophy to construction, Vol. 72, Stanford University, Stanford, CA.

Lean Enterprise Institute (2016). (Léxico Lean: Glossário ilustrado para praticantes do pensamento lean) Lean Lexicon: Illustrated glossary for lean thinking practitioners. Lean Institute Brasil, São Paulo.

Lee, K.-L., and Su, Y. (2013). "Applying Six Sigma to Quality Improvement in Construction." Journal of Management in Engineering, 29(4), 464-470.

Morales, N.S., Valles Ch, A., Torres-Arguelles, V., Martinez G, E., and Hernandez G, A. (2016). "Six Sigma improvement project in a concrete block plant." Construction Innovation-England, 16(4), 526-544.

Oguz, C., Kim, Y.-W., Hutchison, J., and Han, S. (2012). "Implementing Lean Six Sigma: A Case Study in Concrete Panel Production." Proc. 20 th Annual Conference of the International Group for Lean Construction (IGLC20), San Diego, USA.

Ohno, T., and Mito, S. (1988). Just-In-Time for Today and Tomorrow. Productivity Pr, Cambridge, Mass.

Regimento do SiAC (SiAC Rules) - (Especialidade Técnica Execução de Obras (Portaria n 383 de 14/06/2018) Anexos I, II, III e IV) Technical Specialty Execution of Works (Ordinance No. 383 of 06/14/2018) Annexes I, II, III and IV, (Programa Brasileiro de Qualidade e Produtividade do Habitat) Brazilian Habitat Quality and Productivity Program.

Silva, F. F., Filser, L. D., Juliani, F., and Oliveira, O. J. (2018). "Where to direct research in lean six sigma?: Bibliometric analysis, scientific gaps and trends on literature." International Journal of Lean Six Sigma, 9(3), 324-350.

Werkema, M. C. C. (2012) (Criando a cultura Seis Sigma. Série Seis Sigma) Creating the Six Sigma culture. Six Sigma Series. v.2. GEN LTC, São Paulo.

Tannady, H., Gunawan, E., Nurprihatin, F., and Wilujeng, F. R. (2019). "Process improvement to reduce waste in the biggest instant noodle manufacturing company in South East Asia." Journal of Applied Engineering Science, 17(2), 203-212. 